\title{
PENGARUH GAS COOLER DAN FILTER PADA PROSES GASIFIKASI BIOMASSA CANGKANG BIJI KARET MENGGUNAKAN DOWNDRAF GASIFER
}

\author{
Bahtiar Muarif ${ }^{*}$, Dwi Irawan² \\ Program Studi Teknik Mesin, Fakultas Teknik, Universitas Muhammadiyah Metro \\ Jl. Ki Hajar Dewantara 15 A Metro, Lampung. ${ }^{1,2)}$ \\ bahtiarmuarif@yahoo.co.id¹
}

\begin{abstract}
Abstrak
Karet merupakan salah satu komoditas penting di indonesia maupun lingkup internasional. Dari perkebunan karet akan menghasilkan cangkang serta biji karet yang sangat banyak. Untuk para petani, biji karet sebagian hanya dijadikan bibit dan sebagian lain di buang sedangkan cangkang dari biji karet tersebut dianggap sebagai limbah oleh sebagian petani. Dari berbagai upaya cara penaggulangan limbah ini dapat dijadikan sebagai bahan bakar untuk gasifikasi. Tujuan penelitian ini adalah untuk mengetahui pengaruh penambahan gas cooler dan filter terhadap suhu gas yang keluar dari burner dan untuk mengetahui pengaruh penambahan gas cooler dan filter terhadap lama waktu gas produktif yang keluar. Penelitian ini menggunakan variasi rangkaian A1 (reaktor, cyclone, dan burner), A2 (reaktor, cyclone, gas cooler dan burner) dan A3 (reaktor, cyclone, gas cooler, filter dan burner) dan penelitian dilakukan di desa Tanjung Intan, Kec. Purbolinggo, Kab.Lampung timur. Hasil penelitian ini menyebabkan temperatur syngas di burner turun sebesar $18^{\circ} \mathrm{C}$ setelah ditambahkan gas cooler dan turun $24^{\circ} \mathrm{C}$ setelah ditambahkan gas cooler dan filter. Lama syngas yang keluar bertambah 15 detik seteleh ditambahkan gas cooler dan bertambah lama 51 detik dengan pemasangan gas cooler dan filter. Penurunan temperatur syngas berdampak pada kualitas api yang semakin membaik, dimana suhu sebelum menggunakan gas cooler adalah $253^{\circ} \mathrm{C}$ sedangkan setelah penambahan gas cooler dan filter suhu api menjadi $363^{\circ} \mathrm{C}$.
\end{abstract}

Kunci: Cangkang Biji Karet, Gasifikasi, Downdraft, Gas Cooler, Filter.

\section{Pendahuluan}

Biomassa merupakan salah satu bentuk energi terbarukan yang tersedia dalam jumlah besar di indonesia. Karet (Hevea brasiliensis Muell Arg) merupakan tanaman yang berasal dari Brazil. Pada tahun 2000 produksi karet Indonesia sebesar 1,501 juta ton, dan pada tahun 2005 produksi karet sebesar 2,271 juta ton. Luas areal perkebunan karet di Sumatera Selatan hampir 1 juta hektar. Sekitar 900.000 ha adalah perkebunan rakyat, dan selebihnya dikelola oleh perkebunan swasta. Dari perkebunan karet tersebut akan menghasilkan cangkang serta biji karet yang sangat banyak. Untuk para petani, biji karet sebagian hanya dijadikan bibit dan sebagian lain di buang sedangkan cangkang dari biji karet tersebut dianggap sebagai limbah oleh sebagian petani, melihat kondisi di lapangan bahwa limbah ini akan meningkat di masa mendatang seiring dilakukannya pembukaan lahan-lahan baru oleh masyarakat untuk perkebunan karet. Sehingga perlu adanya alternatif cara penanggulangan limbah tersebut. Dari berbagai upaya cara penaggulangan limbah ini dapat dijadikan sebagai bahan bakar untuk gasifikasi.

Gasifikasi bertujuan untuk mengkonversi bahan bakar cair maupun padat menjadi flammable gas menggunakan suatu reaktor yang disebut gasifier. Suatu sistem gasifikasi terdiri atas reaktor gasifikasi yang dilengkapi alat-alat untuk pengkondisian bahan bakar dan producer gas. Berdasarkan arah fixed bad, gasifier dapat dibedakan menjadi 3 yaitu reaktor aliran berlawanan (updraft gasifier), reaktor aliran menyilang (crossdraft gasifier), dan reaktor aliran searah (downdraft gasifier). Dari ketiga jenis reaktor ini, reaktor tipe 
downdraft dinilai paling sesuai karena kadar tar yang dihasilkan relatif rendah [1].

Setiap unit gasifikasi memiliki karakteristik-karakteristik tertentu bergantung pada umpan biomassa yang berpengaruh terhadap kinerja unit tersebut. Dalam satu unit gasifikasi terdapat beberapa bagian yang sangat berpengaruh dalam proses gasifikasi biomassa, seperti bagian reaktor, gas cooler, filter,dll. Dalam kinerja unit gasifikasi ini, penambahan gas cooler dan filter cukup berpengaruh.

Gas cooler merupakan salah satu alat pemurnian gas dimana berfungsi untuk menurunkan kadar bahan yang bisa dikondensasi (misalnya uap air) dari tabung reaktor. Uji performansi downdraft gasifier (reaktor gasifikasi) biomass tipe imbert dengan gas cooler sebagai salah satu unit pemurniannya. Pada penelitiannya untuk uji performansi gas cooler, laju perpindahan panas sebesar $29.304 \mathrm{kkal} / \mathrm{jam}$, penurunan tekanan dari gas yang masuk ke gas cooler $24.4 \mathrm{~Pa}$, dan efisiensi gas cooler $17.2 \%$ [2].

Filter adalah bagian yang berfungsi untuk membersihkan gas dari debu dan tar. Kajian pembersihan dan pendinginan gas produksi gasifikasi biomassa menggunakan filter serabut kelapa. Pada penelitiannya Penggunaan variasi kepadatan serabut kelapa $34,83 \mathrm{~kg} / \mathrm{m}^{3}$ pada pembersihan dan pendinginan gas produksi gasifikasi menggunakan filter serabut kelapa memberikan kinerja terbaik dengan rata-rata penurunan suhu $4,28{ }^{\circ} \mathrm{C}$, rata-rata penyaringan tar 280 gram dan rata-rata lama nyala api kompor gasifier 27,33 menit [3].

Untuk mengetahui bagaimana pengaruh kedua bagian ini terhadap kinerja unit gasifikasi ini nanti, maka perlu dilakukan pengujian. Pada penelitian ini, pengujian menggunakan unit gasifikasi biomassa tipe downdraft dengan menggukan biomassa cangkang biji karet.

\section{Landasan Teori}

\section{A. Gasifikasi}

Gasifikasi adalah proses konversi energi dari bahan bakar yang mengandung karbon (padat maupun cair) menjadi gas yang disebut syngas (synthetis gas) atau gas sintetis dengan cara oksidasi parsial dengan temperatur tinggi.

\section{B. Downdraft Gasifier}

Berikut prinsip kerja dari alat gasifikasi tipe downdraft dengan menggunakan bahan bakar cangkang biji karet. Bahan bakar cangkang biji karet dibakar di dalam reaktor dengan memasukkan sedikit demi sedikit. Setelah cangkang biji karet yang berada dibawah terbakar, bahan bakar dinyalakan dari bawah reaktor dengan terlebih dahulu membakar potongan-potongan kertas untuk memancing api sehingga cangkang biji karet terbakar. Kemudian cangkang karet dimasukkan sedikit demi sedikit hingga memenuhi reaktor.

Gas-gas yang terbentuk dari proses gasifikasi di reaktor, keluar melalui pipa menuju cyclone. Cyclone berfungsi sebagai penyaring abu cangkang biji karet yang memungkinkan terbawa keluar karena terdorong oleh hembusan angin dari blower. Pada cyclone ini gas yang terhirup akan berputar, sehingga akan terpisah antara gas dan abu, dimana gas akan keatas sementara abu akan kebawah.

Kemudian gas diteruskan ke gas cooler. Bentuk gas cooler yang berkelok memungkinkan untuk gas kehilangan panas dan tekanan. Gas yang berkurang panasnya, akan mempermudah pemisahan gas dengan uap air dan tar nantinya. Setelah melalui gas cooler, lalu gas diteruskan ke filter. Pada filter gas dipisahkan dari tar dan partikulat lain yang kemungkinan masih ada, agar pada saat pembakaran di burner nanti tidak banyak menimbulkan jelaga. Lalu gas langsung diteruskan menuju lubang burner. Setelah gas melewati burner, gas dibakar untuk menghasilkan api.

Kelebihan gasifier downdraft:

a. Tar yang terdapat pada syngas sangat sedikit $(0.1 \%)$, sehingga biaya untuk proses pembersihan gas lebih sedikit.

b. Kandungan mineral tertinggal sebagai abu, sehingga kebutuhan akan cyclone dapat dikurangi.

c. Desain sederhana dan murah, sehingga bisa dibuat untuk skala kecil. 
Kekurangan gasifier downdraft:
a. Membutuhkan proses pengeringan, karena umpan diharapkan memiliki kadar air dibawah $20 \%$.
b. Syngas yang dihasilkan keluar pada suhu yang tinggi sehingga membutuhkan heat recovery system.
c. Jumlah karbon yang tidak terkonversi 4- $7 \%$ [4].

\section{Gas cooler}

Gas cooler merupakan salah satu alat pemurnian gas dimana berfungsi untuk menurunkan kadar bahan yang bisa dikondensasi (misalnya uap air) dari tabung reaktor. Gas cooler adalah sebuah alat yang digunakan untuk membuang kalor ke lingkungan, sehingga uap air yang bercampur syngas akan mengembun dan berubah fasa dari uap ke cair. Sebelum masuk ke gas cooler, syngas yang bercampur dengan uap air berupa uap yang bertemperatur dan bertekanan tinggi, sedangkan setelah keluar dari syngas akan terpisah dengan uap air, dan bertemperatur lebih rendah dan bertekanan sama (tinggi) seperti sebelum masuk ke gas cooler.

\section{Filter}

Filter merupakan bahan berpori yang memungkinkan gas untuk menembus namun mencegah berlalunya partikel. Filter ini secara efektif menghilangkan partikel berdiameter dalam kisaran 0,5-100 $\mu \mathrm{m}$ yang terdapat pada aliran gas. Filter dapat dirancang untuk menghapus hampir semua ukuran partikel, termasuk menjangkau ukuran sub-mikron, tetapi perbedaan tekanan di filter akan meningkat sejalan dengan pengecilan ukuran pori-pori. Akibatnya, ada kendala teknis dan ekonomis pada pemisahan partikel berukuran sekitar $0,5 \mu \mathrm{m}$, terutama jika volume gas yang harus ditangani berjumlah besar. filter secara berkala dibersihkan dengan cara mengalirkan gas pada arah yang berlawanan dari proses filtrasi. Untuk mengurangi beban partikel secara keseluruhan, filter ini biasanya ditempatkan setelah cyclone.

\section{E. Efisiensi temperatur pada gas cooler}

Efisiensi gas cooler disini adalah bagaimana penurunan suhu gas setelah ditambahkan gas cooler, dengan membandingkan gas produktif yang masuk dan keluar dari gas cooler. Dapat dihitung dengan persamaan:

$\eta \mathrm{f}=\frac{T 1-T 2}{T 1} \times 100 \%$

Dimana:

$\eta \mathrm{f}=$ Efisiensi temperatur pada gas cooler

$\mathrm{T} 1$ = Rata- rata suhu gas produktif sebelum masuk gas cooler $\left({ }^{\circ} \mathrm{C}\right)$

$\mathrm{T} 2$ = Rata- rata suhu gas produktif sesudah keluar gas cooler $\left({ }^{\circ} \mathrm{C}\right)$

\section{Metode Penelitian}

Untuk mengetahui bagaimana pengaruh penambahan gas cooler dan filter terhadap kinerja gasifikisai downdraft, dimana bahan bakunya menggunakan biomassa cangkang biji karet 500 gr, serta gas cooler menggunakan pendingin udara bebas, dan dilakukan dengan memvariasikan rangkaian A1 (reaktor, cyclone, burner), A2 (reaktor cyclone, gas cooler, dan burner), dan A3 (reaktor, cyclone, gas cooler, filter, burner).

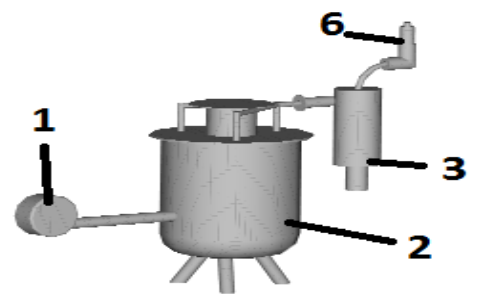

Gambar 1. Rangkaian A1

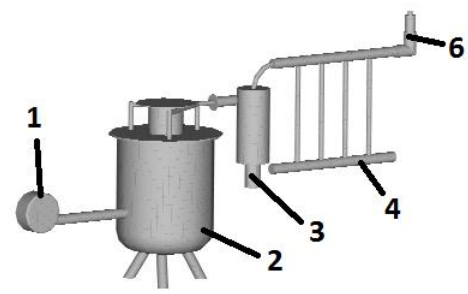

Gambar 2. Rangkaian A2

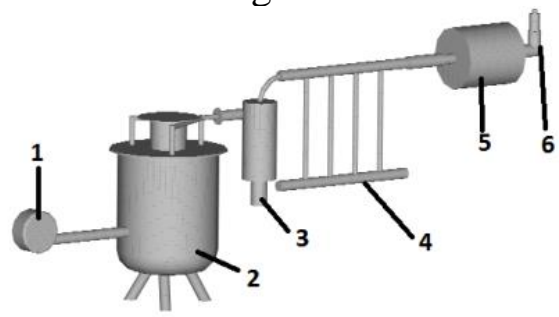

Gambar 3. Rangkaian A3

Komponen alat: 
1. Blower

2. Reaktor

3. Cyclone

4. Gas cooler

5. Filter

6. Burner

\section{Hasil dan Pembahasan}

\section{A. Suhu gas di burner}

Berikut ini rata rata suhu gas produktif dari setiap rangkaian di gambarkan dalam bentuk diagram batang.

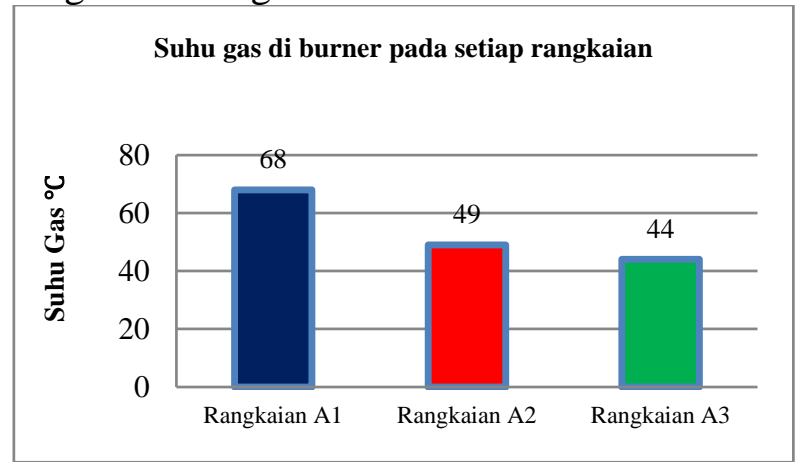

Gambar 4. Diagram suhu syngas di burner pada setiap rangkaian

Salah satu faktor yang mempengaruhi kinerja gasifikasi adalah suhu gas hasil gasifikasi (syngas). Pada diagram diatas terlihat bahwa pada rangkaian A1 suhu syngas paling tinggi yakni pada suhu rata rata $68^{\circ} \mathrm{C}$. Untuk rangkaian $\mathrm{A} 2$ suhu syngas suhu syngas rata rata pada suhu $49^{\circ} \mathrm{C}$, Selisih cukup jauh dengan rangkaian A1. Hal ini dikarenakan pada rangkaian A2 ditambahkan Gas cooler. Disini terlihat bahwa bahwa selisih $19^{\circ} \mathrm{C}$ dari rangkaian A1 (tanpa gas cooler), jadi penurunan suhu karena pemasangan gas cooler rata rata sebesar $19^{\circ} \mathrm{C}$.

Pada rangkaian A3 suhu syngas berada pada $44^{\circ} \mathrm{C}$. Hal ini karena pada rangkaian A3 terdapat gas cooler dan filter sehingga terjadi penurunan perbedaan yang signifikan dari rangkaian A1 yang selisih rata rata $24^{\circ} \mathrm{C}$. Dan terjadi penurunan yang tidak terlalu jauh dari rangkaian A2 yakni sebesar $5^{\circ} \mathrm{C}$. Filter yang berbentuk tabung, sehingga terjadi pembesaran penampang, yang berdampak pada penurunan suhu syngas.

Untuk mengetahui bagaimana pengaruh penurunan suhu terhadap nyala api, Berikut ini grafik hubungan suhu api dan suhu gas di burner dari setiap rangkaian gasifikasi:

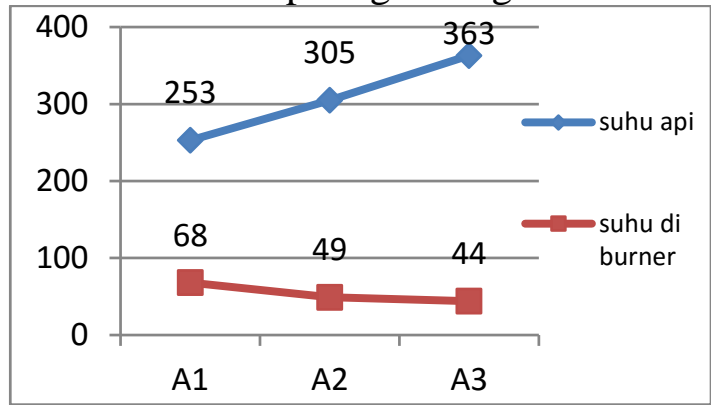

Gambar 5. Grafik perbandingan suhu api dan suhu gas

Dari grafik diatas terlihat bahwa pada rangkaian A1 suhu api hanya mencapai $253^{\circ} \mathrm{C}$ dengan suhu gas yang keluar di burner sebesar $68^{\circ} \mathrm{C}$ karena api yang dihasilkan memudar atau gas tidak terbakar sempurna. Pada rangkaian A2 suhu api mencapai $303^{\circ} \mathrm{C}$ dengan syngas yang keluar di burner sebesar $49^{\circ} \mathrm{C}$, ini karena api yang dihasilkan terlihat lebih baik dibandingkan dengan api pada rangkaian A1, namun masih terlihat ada gas tidak terbakar sempurna. Sedangkan pada rangkaian A3 suhu api bisa mencapai $363^{\circ} \mathrm{C}$ dengan suhu gas yang keluar di burner $45^{\circ} \mathrm{C}$ hal ini karena api yang dihasilkan terlihat terbakar lebih sempurna.

Dari penjelasan diatas terlihat bahwa penelitian ini seperti penelitian yang dilakukan oleh [5], bahwa penurunan suhu gas produktif setelah penambahan gas cleaner disebabkan oleh hilangnya sebagian unsur pengotor (tar dan partikulat lainnya) yang memiliki kontribusi terhadap gas mampu bakar. Sehingga setiap penurunan suhu gas produktif, akan mempengaruhi kualitas syngas yang keluar.

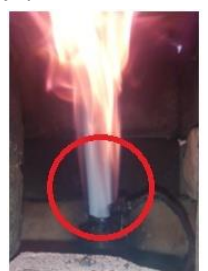

A1

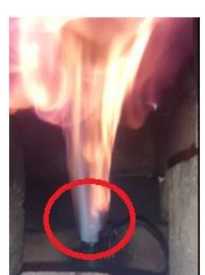

A2

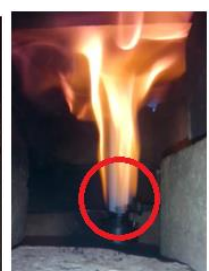

A3
Gambar 6. Visualisasi Api

\section{B. Lama Gas Produktif}

Berikut ini rata rata lama gas produktif dari setiap rangkaian di gambarkan dalam bentuk diagram batang 


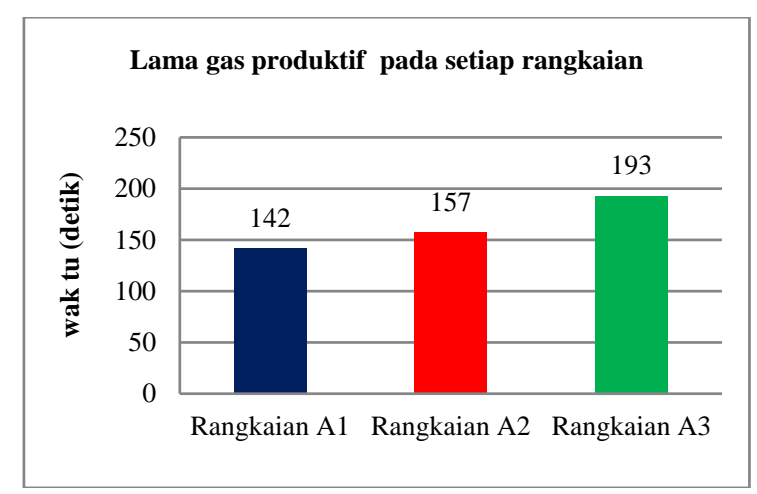

Gambar 7. Grafik perbandingan lama produksi gas

Salah satu faktor yang mempengaruhi kinerja gasifikasi adalah lama gas hasil gasifikasi (syngas). Pada diagram diatas terlihat bahwa pada rangkaian A1 lama syngas yang paling cepat yakni pada waktu rata rata 142 detik, hal ini disebabkan karena pada rangkaian A1 hanya menggunakan Reaktor cyclone dan burner, sehingga gas hasil gasifikasi dari reaktor hanya melewati cyclone dan burner. Oleh karna itu uap air dan tar yang ada pada syngas tidak banyak ber kurang, yang mempengaruhi terhadap nyala api yang cepat mati.

Untuk rangkaian A2 lama syngas rata rata pada 157 detik, Selisih tidak jauh dengan rangkaian A1. Hal ini dikarenakan pada rangkaian A2 ditambahkan Gas cooler. Fungsi Gas cooler disini untuk menurunkan kadar bahan yang dapat dikondensasi (misalnya uap air), namun hal ini tidak terlalu berdampak pada lama syngas yang keluar, yang hanya selisih 15 detik lebih lama dari rangkaian A1.

Pada diagram diatas dapat dilihat bahwa pada rangkaian A3 lama syngas yang keluar selama 193 detik. Terjadi penurunan perbedaan yang signifikan dari rangkaian A1 dan A2 yang selisih rata rata 51 detik dan 38 detik. Hal ini karena pada rangkaian A3 terdapat gas cooler dan filter. Filter pada dasarnya digunakan untuk membersihakan gas dari unsur unsur; senyawasenyawa sulfur, senyawa-senyawa nitrogen, debu yang terangkut oleh gas, kelembaban dari gas, temperatur gas.

Lamanya waktu nyala api juga terpengaruh terhadap tempat dimana dilakukan pengujian, diluar atau di dalam ruangan karena syngas sangat sensitif dengan hembusan angin. Sehingga hasil nyala api tidak dapat konstan karena selalu padam saat terhembus angin.

\section{Kesimpulan}

1. Temperatur syngas di burner turun sebesar $18^{\circ} \mathrm{C}$ setelah ditambahkan gas cooler dan turun $24^{\circ} \mathrm{C}$ setelah ditambahkan gas cooler dan filter. Suhu rangkaian A1 (reaktor, cyclone, burner), memiliki suhu gas di burner $68^{\circ} \mathrm{C}$, rangkaian A2 (reaktor, cyclone, gas cooler dan burner) memiliki suhu gas di burner $49^{\circ} \mathrm{C}$ dan rengkaian A3 (reaktor, cyclone, gas cooler, filter dan burner) memiliki suhu gas di burner $44{ }^{\circ} \mathrm{C}$. Penambahan rangkaian, akan mempengaruhi penurunan suhu syngas yang berdampak pada kualitas api yang semakin baik.

2. Lama syngas yang keluar bertambah 15 detik seteleh ditambahkan gas cooler, dan bertambah lama 51 detik dengan pemasangan gas cooler dan filter. Lama waktu gas yang keluar pada rangkaian A1 (reaktor, cyclone dan burner) adalah 142 detik, pada rangkaian A2 (reaktor, cyclone, gas cooler dan burner) adalah 157 detik, dan pada rangkaian A3 (reaktor, cyclone, gas cooler, filter dan burner) adalah 193 detik.

\section{DAFTAR PUSTAKA}

[1]. Reed, T.B. and Agua Das, 1988, Handbook of Biomass Downdraft Gasifier Engine Systems, Solar Energy Research Institute, Colorado

[2]. Jakle, Rahmad. 2006. Uji Performansi Down-Draft Gasifier (Reaktor Gasifikasi) Biomass Tipe Imbert Dengan Gas Cooler Sebagi Salah Satu Unit Pemurnianya. Tugas Akhir Teknik Pertanian, Institut Pertanian Bogor. Bogor.

[3]. Rakhmatuloh, Akbar. 2013. Kajian Pembersihan Dan Pendinginan Gas Produksi Gasifikasi Biomassa Menggunakan Filter Serabut Kelapa. Tugas Akhir jurusan Teknik Pertanian, Universitas gajah mada. Yogyakarta.

[4]. Ciferno, Jared P., John J. Marano, 2002, Benchmarking Biomass Gasification Technologies for Fuels, Chemicals and Hydrogen Production. U.S. Department of Energy and National Energy Technology Laboratory.

[5]. Daniel,Hary,S. 2012. Kajian Pengaruh Kondisi Operasi Wet Gas Cleaner 
Terhadap Jumlah Kandungan Tar Dan Temperatur Producer Gas Hasil Gasifikasi. Skripsi Jurusan Teknik Mesin Fakultas Teknik Universitas Indonesia. Depok 